\title{
SOME BIOCHEMICAL AND IMMUNOLOGICAL PROPERTIES OF A 5'-NUCLEOTIDASE OF BULL SEMINAL PLASMA
}

\author{
J. STRZEŻEK AND A. WOEOS \\ Institute of Animal Physiology and Biochemistry, \\ Agricultural-Technical Academy, Olsztyn, Poland
}

(Received 28th February 1974)

Since the isolation by Heppel \& Hilmoe (1955) of $5^{\prime}$-nucleotidase from bull seminal plasma, several papers on its biochemical properties in the semen of bulls and other animals have been published (Mann, 1964; Levin \& Bodansky, 1966; Pilcher \& Scott, 1967; Buruiana \& Dema, 1968; Strzeżek \& Wołos, 1972; Strzeżek, Wolos \& Glogowski, 1972). Unfortunately, the results of the studies have, in many cases, been contradictory, and the rôle of the enzyme in semen is still unclear.

This study is a further attempt to describe the biochemical and immunological characteristics of the 5'-nucleotidase separated from bull seminal plasma.

Bull semen collected by artificial vagina was centrifuged twice for successive 15 -min periods at $12,800 \mathrm{~g}$. Seminal plasma was stored at a temperature of $-20^{\circ} \mathrm{C}$. Isolation of $5^{\prime}$-nucleotidase (EC 3.1.3.5) was carried out by the method described by Heppel \& Hilmoe (1955). The activity of the enzyme was determined by an increase in the amount of inorganic phosphorus in seven samples incubated at $37^{\circ} \mathrm{C}$, and was expressed as $\mu \mathrm{mol}$ phosphorus $/ \mathrm{mg}$ protein released during 5 or $15 \mathrm{~min}$ of incubation. Inorganic phosphorus was determined by the method of Fiske \& Subbarow (1925), and total protein by the method of Weichselbaum (1946). The following substrates were used in determining the activity of 5'-nucleotidase; 5'-AMP (Koch-Light), 5'-dAMP, 5'-dCMP, 5'-GMP, 5'-UMP, 5'-TMP (Calbiochem). Antiserum against 5'-nucleotidase was obtained by applying Freund's complete adjuvant (Bacto-Difco). Gel precipitation (Ouchterlony, 1958) and immuno-disc-electrophoresis techniques (Maurer, 1968) were used to test anti-5'-nucleotidase rabbit serum. Preparations for electrophoretic separation on polyacrylamide gel were set up according to the methods described by Ornstein (1964) and Davies (1964).

The specific activity of the 5 '-nucleotidase preparation, determined at $\mathrm{pH} 8.5$ in the presence of $\mathrm{Mg}^{++}$ions, was almost 100 times higher than the initial activity of seminal plasma if 5 -AMP substrate was used. With $\beta$-glycerophosphate, the activity of the enzyme (at $\mathrm{pH} 8.5$ ) was only $6.6 \%$ of the activity observed with $5^{\prime}$-AMP.

As with almost all phosphates, the 5'-nucleotidase of bull seminal plasma was activated by $\mathrm{Mg}^{++}$ions. Two $\mathrm{pH}$ optima ( $\mathrm{pH} 8.5$ and 9.5) were noted in the presence of $\mathrm{Mg}^{++}$ions with $5^{\prime}$-AMP as the substrate, while only one 
optimum was observed if there were no $\mathrm{Mg}^{++}$ions in the incubated mixture. These results are presented in Text-fig. 1. If $\mathrm{Mg}^{++}$ions were not present, the activity of 5'-nucleotidase at $\mathrm{pH} 8.5$ was lower by $16.6 \%$.

When the relation between the enzyme and substrate was unfavourable, and especially when the concentration of the enzyme was too high, during the 15-min incubation, a linear dependence was observed between the speed of reaction and the substrate concentration up to 4 mM-AMP (Text-fig. 2). At higher substrate concentrations, i.e. $5 \mathrm{~mm}$ and $10 \mathrm{~mm}$, an inhibition was noted,

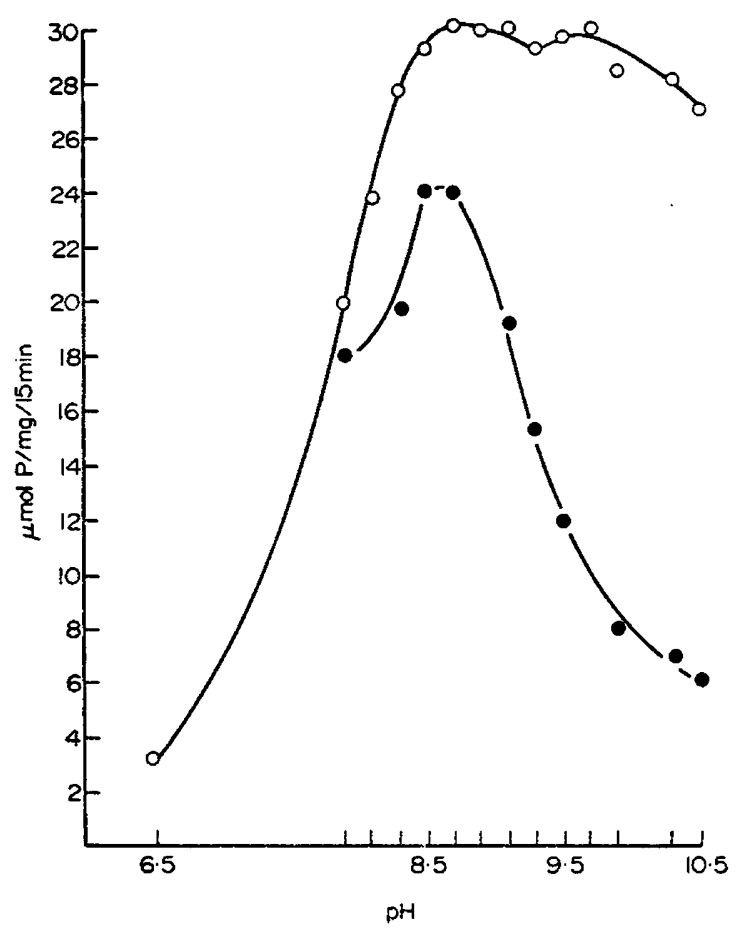

TExT-FIG. 1. The effect of $\mathrm{pH}$ and $\mathrm{Mg}^{++}$ions on the activity of bull seminal plasma $5^{\prime}$-nucleotidase. The reaction mixture contained $0.1 \mathrm{M}$-gly-NaOH, $2 \mathrm{mM}-5^{\prime}-\mathrm{AMP}$, and $0.057 \mathrm{mg}$ protein $/ \mathrm{ml}$. $\mathrm{O}$, With $\mathrm{MgCl}_{2} ; 0$, without $\mathrm{MgCl}_{2}$.

amounting to $16 \%$ and $22 \%$ respectively. Such kinetics did not allow a determination of the affinity of the enzyme for substrate, or for an estimation of the Michaelis-Manten constant $\left(\mathrm{K}_{\mathrm{m}}\right)$.

Text-figure 3 illustrates the enzymatic reaction which occurred with lower $(50 \%)$ concentrations of the enzyme when the incubation was reduced to $5 \mathrm{~min}$. In such conditions, the maximal speed of reaction occurred in the presence of 3 to $4 \mathrm{~mm} 5$-AMP. If the concentration was increased to $5 \mathrm{~mm}$, a substrate inhibition amounting to $19 \%$ (compared to maximal speed) was observed. The $\mathrm{K}_{\mathrm{m}}$, estimated by the slope of Lineweaver-Burk, was $9 \cdot 1 \times 10^{-4} \mathrm{M}$.

Text-figure 4 illustrates the results of studies on the substrate affinity of $5^{\prime}$ nucleotidase for various $5^{\prime}$-nucleotides in the presence of $\mathrm{Mg}^{++}$ions, and at two different $\mathrm{pH}$ optima. The enzyme most strongly hydrolysed 5'-AMP, but 


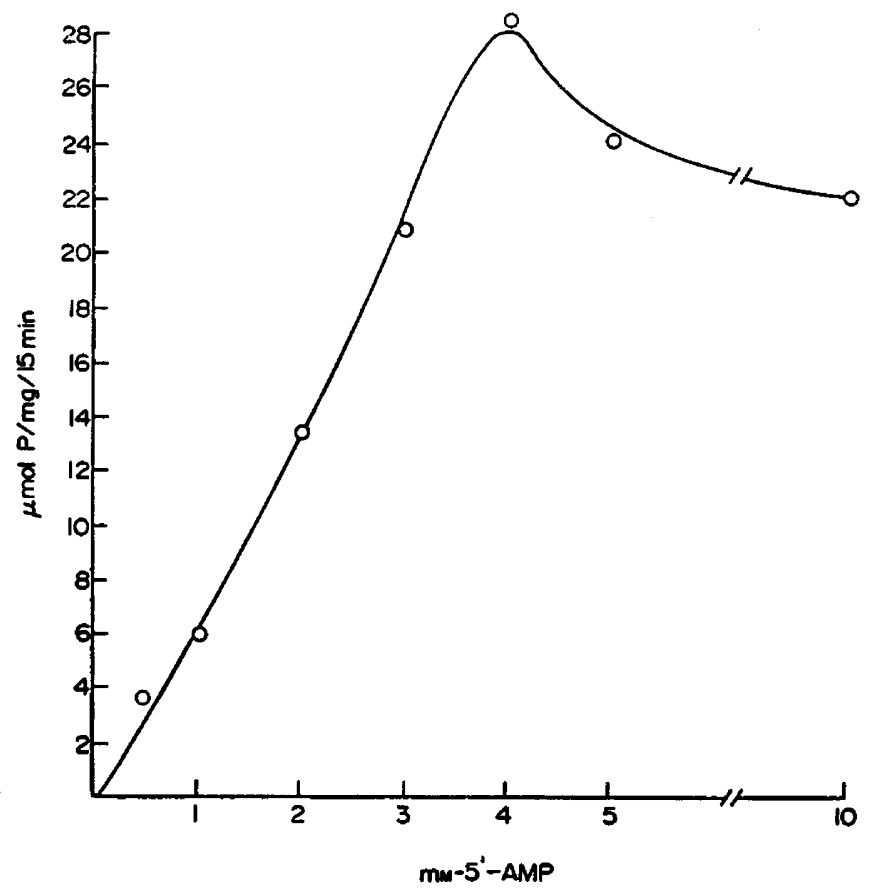

TEXT-pic. 2. The effect of substrate concentration on the activity of bull seminal plasma $5^{\prime}$-nucleotidase during incubation at $37^{\circ} \mathrm{C}$ for $15 \mathrm{~min}$. The reaction mixture contained 0.1 M-gly-NaOH, pH 8.5, $10 \mathrm{~mm}-\mathrm{MgCl}_{2}$ and $0.115 \mathrm{mg}$ protein $/ \mathrm{ml}$.

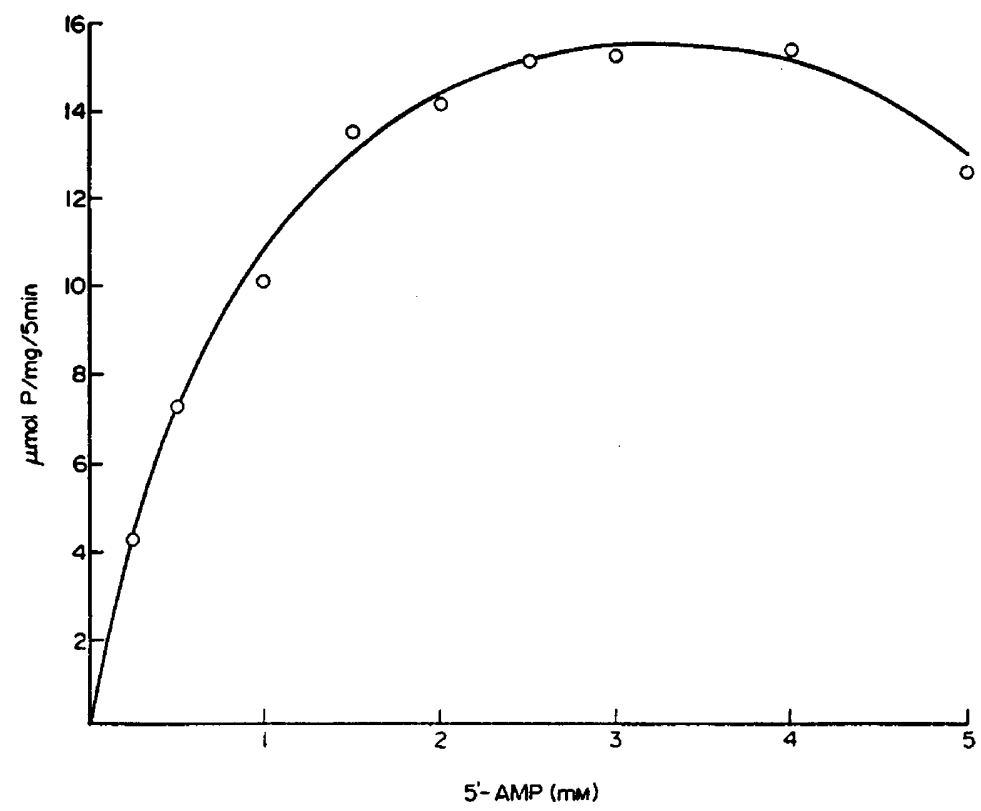

TEXT-rig. 3. The effect of substrate concentration on the activity of bull seminal plasma $5^{\prime}$-nucleotidase during incubation at $37^{\circ} \mathrm{C}$ for $5 \mathrm{~min}$. The reaction mixture contained 0.1 $\mathrm{M}-\mathrm{gly}-\mathrm{NaOH}, \mathrm{pH} 8.5,2 \mathrm{mM}-\mathrm{MgCl}_{2}$ and $0.057 \mathrm{mg}$ protein $/ \mathrm{ml}$. 


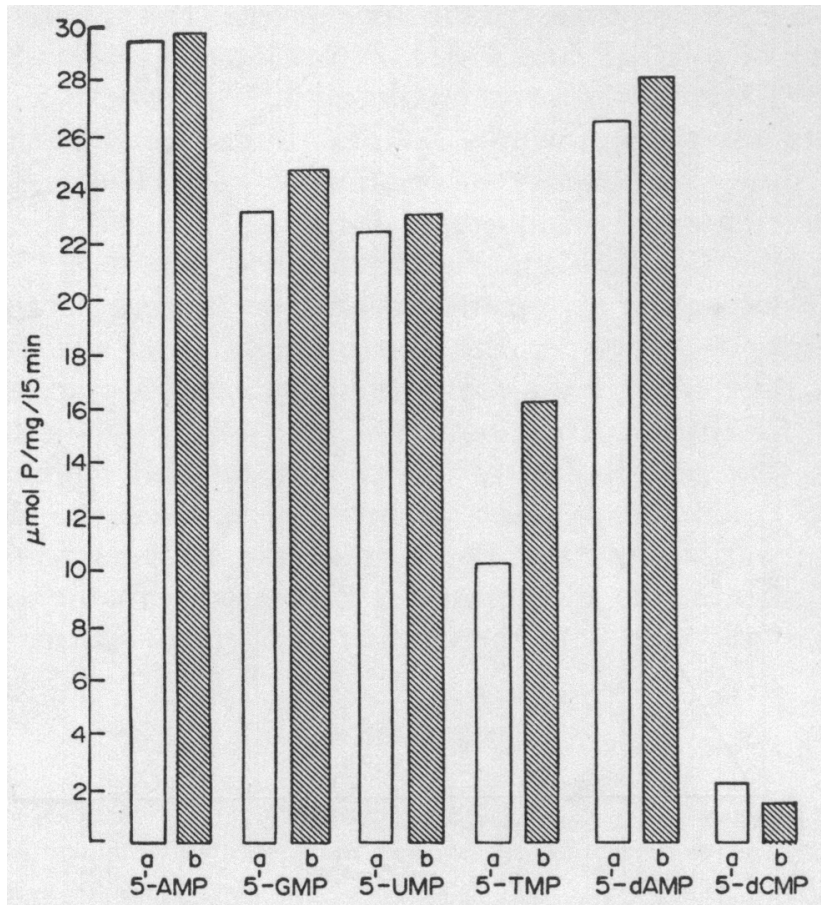

Text-FIG. 4. The activity of bull seminal plasma $5^{\prime}$-nucleotidase in the presence of six different nucleotide substrates at $\mathrm{pH} 8.5$ (a) and $\mathrm{pH} 9.5$ (b). The reaction mixture contained $0.1 \mathrm{M}$-gly-NaOH, $2 \mathrm{~mm}-\mathrm{MgCl}_{2}, 2 \mathrm{~mm}$-substrate and $0.057 \mathrm{mg}$ protein $/ \mathrm{ml}$.

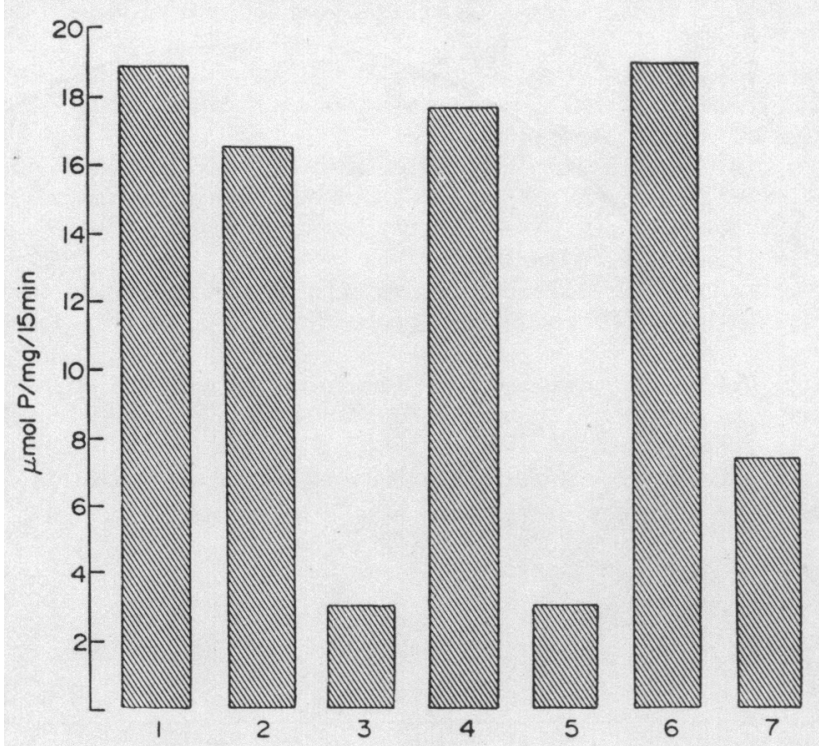

Text-Fig, 5. The effect of antiserum on the activity of bull seminal plasma $5^{\prime}$-nucleotidase. The reaction mixture contained $0.1 \mathrm{M}-\mathrm{gly}-\mathrm{NaOH}, \mathrm{pH} \mathrm{8.5,2} \mathrm{mm}-\mathrm{MgCl}_{2}, 2 \mathrm{~mm}-5^{\prime}-$ AMP and $0.057 \mathrm{mg}$ enzyme/ml. (1) Control; (2) with normal serum-3.3 $\mathrm{mg}$ protein $/ \mathrm{ml}$ sample; (3) with anti-5'-nucleotidase serum-3.3 $\mathrm{mg}$ protein/ml sample; (4) and (6) with inactivated normal serum-3.3 $\mathrm{mg}$ and $0.33 \mathrm{mg}$ protein $/ \mathrm{ml}$ sample; (5) and (7) with inactivated anti-5'-nucleotidase serum $-3.3 \mathrm{mg}$ and $0.33 \mathrm{mg}$ protein $/ \mathrm{ml}$ sample. 
5'-dAMP was hydrolysed almost to the same degree. The activity of the enzyme in the presence of $5^{\prime}$-GMP and $5^{\prime}$-UMP was lower by almost $23 \%$, and at $\mathrm{pH} 9.5$ with $5^{\prime}-\mathrm{TMP}$, it was lower by almost $46 \%$. Towards $5^{\prime}$-dCMP, it was almost 15 times lower than towards 5'-AMP. Bull seminal plasma $5^{\prime}$-nucleotidase did not show any activity in relation to $3^{\prime}$-nucleotides at either $\mathrm{pH}$.

The 5'-nucleotidase antiserum caused a distinct change in the activity of the enzyme. As seen in Text-fig. 5, maximal inhibition (about 75\%) was observed when the ratio of antiserum protein to enzyme protein exceeded 100:1. If the ratio was lowered ten times, the degree of inhibition was still about $60 \%$. There were no differences in the degree of inhibition of 5 '-nucleotidase activity if the antiserum was preincubated at $56^{\circ} \mathrm{C}$.

Our preliminary immunological observation on bull seminal plasma and sperm extracts (spermatozoa were washed several times) in the presence of $5^{\prime}$-nucleotidase antiserum have shown that the enzyme has immunogenic properties. Most probably the enzyme is associated with the antigens of bull seminal plasma, and also with the coating antigens of spermatozoa.

\section{REFERENCES}

Buruiana, L. M. \& Dema, A. (1968) Sur la cinétique de la ribonucléotide phosphohydrolase (E.C. 3.1.3.5) du liquide séminal. Rev. rom. Biochem. 5, 91 .

Davies, B. J. (1964) Disc electrophoresis. II. Method and application to human serum proteins. Ann. N.Y. Acad. Sci. 121, 404.

Fiske, G. H. \& Subbarow, Y. (1925) Phosphor determination in biological fluids. F. biol. Chem. 66, 375.

Hepped, I. A. \& Hilmoe, R. J. (1955) 5'-Nucleotidase. In Methods in Enzymology, vol. 2, p. 546. Eds. S. Colowick and N. Kaplan. Academic Press, New York.

Levin, S. J. \& Bodansky, O. (1966) The double pH optimum of 5 '-nucleotidase of bull seminal plasma. 7. biol. Chem. 241, 51 .

Mann, T. (1964) The Biochemistry of Semen and of the Male Reproductive Tract. Methuen, London.

MAURER, R. (1968) Disk-electrophorese. Theorie und praxis der diskontinierlicken Polyacrylamidgel-Electrophorese. Walter de Gruyter, Berlin.

Ornstein, L. (1964) Disc electrophoresis. I. Background theory. Ann. N.Y. Acad. Sci. 121, 321.

Ouchterlony, O. (1958) Diffusion in gel methods for immunological analysis. Prog. Allergy, $5,1$.

PILcher, G. W. T. \& Scott, T. G. (1967) Electrophoretic heterogenity of bovine seminal plasma 5'-nucleotidase. Biochem. F. 104, 410.

Strzeżex J., \& Wozos, A. (1972) Wskaźniki biochemiczne w zastoswaniu do oceny jakości nasienia zwierząt gospodarskich. IV. Właściwości biochemiczne 5'-nukleotydazy tryka. Medycyna wet. $28 ; 174$.

StrzeżeK, J., Wozos, A. \& Glogowski J. (1972) Wskaźniki biochemiczne w zastosowaniu do oceny jakości nasienia zwierząt gospodarskich. V. Immunogenne wlasciwości 5'-nukleotydazy plazmy nasienia tryka. Medycyna wet. 28, 679 .

Wetchselbaum, T. E. (1946) An accurate and rapid method for the determination of proteins in small amounts of blood serum and plasma. Am. F. clin. Path. tech. Suppl. 10, 40. 